\title{
Signal hyperintensity of the callosum after ventriculoperitoneal shunting
}

\section{Figure Fluid-attenuated inversion recovery MRI}
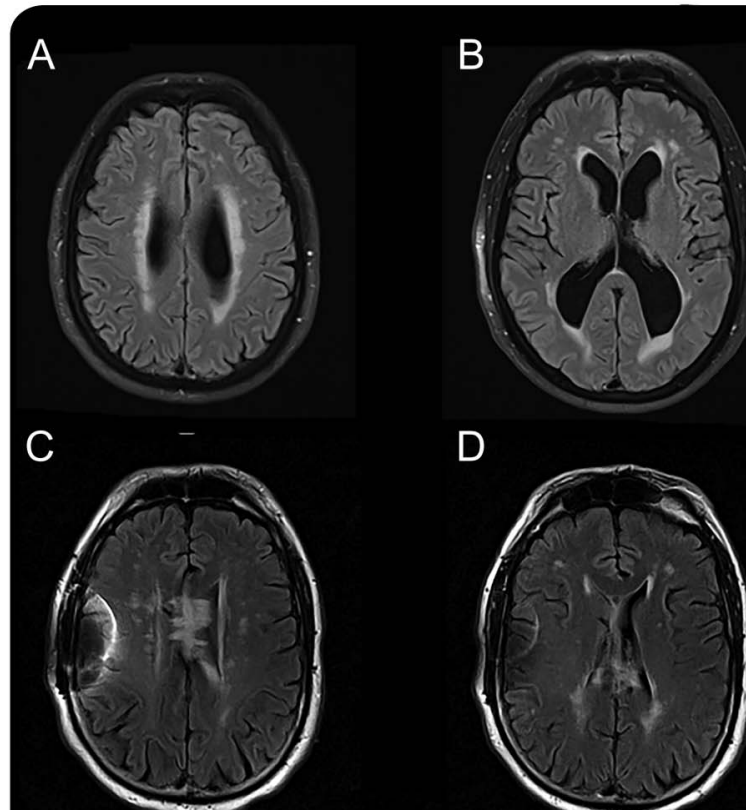

D

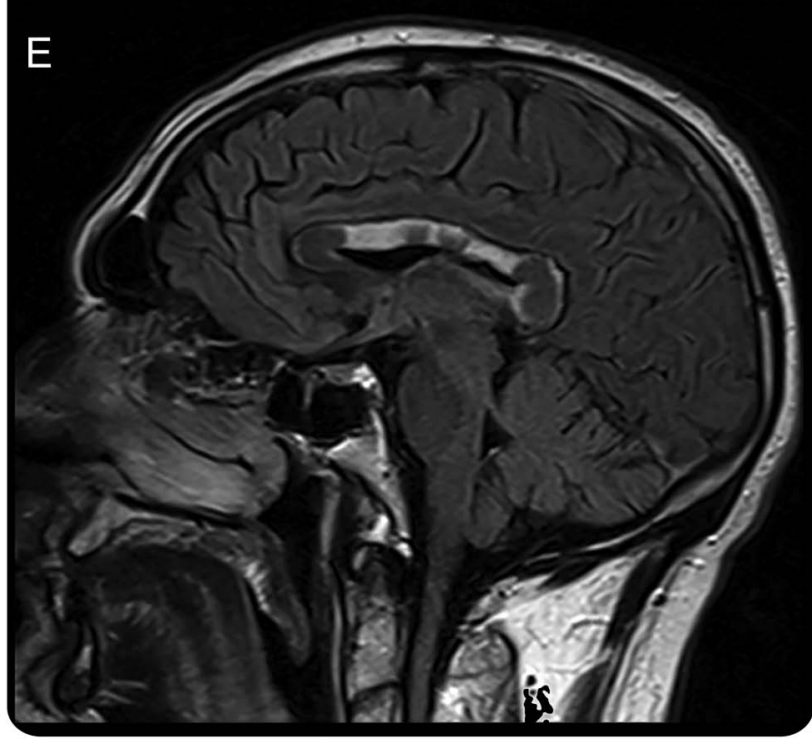

Fluid-attenuated inversion recovery MRI before $(A, B)$ and after $(C-E)$ ventriculoperitoneal shunting shows postoperative ventricular decompression and hyperintensities involving the body of the corpus callosum, best illustrated on the sagittal view (E).

A 66-year-old man underwent ventriculoperitoneal shunting for communicating hydrocephalus. MRI 10 months postoperatively, done for transient headache, showed new fluid-attenuated inversion recovery/T2 hyperintensities within the corpus callosum (figure), while examination revealed improved gait and bladder control with no evidence of a callosal disconnection syndrome. 
Prominent signal hyperintensity within the callosum, often sparing the splenium, follows ventriculoperitoneal shunting in a minority of patients with severe, chronic hydrocephalus. This phenomenon may arise from interstitial edema after decompression of the callosum against the falx. ${ }^{1,2}$ While striking, MRI changes are clinically unapparent, and familiarity with this imaging finding is important so as to avoid unnecessary interventions.

Joseph M. Ferrara, MD

From Virginia Tech/Carilion School of Medicine, Roanoke.

Study funding: No targeted funding reported.

Disclosure: The author reports no disclosures relevant to the manuscript. Go to Neurology.org for full disclosures.

Correspondence to Dr. Ferrara: jmferrara@carilionclinic.org

1. Ginat DT, Prabhu SP, Madsen JR. Postshunting corpus callosum swelling with depiction on tractography. J Neurosurg Pediatr 2013;11:178-180.

2. Lane JI, Luetmer PH, Atkinson JL. Corpus callosal signal changes in patients with obstructive hydrocephalus after ventriculoperitoneal shunting. AJNR Am J Neuroradiol 2001;22:158-162. 


\section{Neurology}

\section{Signal hyperintensity of the callosum after ventriculoperitoneal shunting}

Joseph M. Ferrara

Neurology 2015;84;1609-1610

DOI 10.1212/WNL.0000000000001464

\section{This information is current as of April 13, 2015}

\author{
Updated Information \& \\ Services
}

References

Subspecialty Collections

Permissions \& Licensing

Reprints including high resolution figures, can be found at: http://n.neurology.org/content/84/15/1609.full

This article cites 2 articles, 1 of which you can access for free at: http://n.neurology.org/content/84/15/1609.full\#ref-list-1

This article, along with others on similar topics, appears in the following collection(s):

All Clinical Neurology

http://n.neurology.org/cgi/collection/all_clinical_neurology MRI

http://n.neurology.org/cgi/collection/mri

Information about reproducing this article in parts (figures,tables) or in its entirety can be found online at:

http://www.neurology.org/about/about_the_journal\#permissions

Information about ordering reprints can be found online:

http://n.neurology.org/subscribers/advertise

Neurology ${ }^{\circledR}$ is the official journal of the American Academy of Neurology. Published continuously since 1951, it is now a weekly with 48 issues per year. Copyright @ 2015 American Academy of Neurology. All rights reserved. Print ISSN: 0028-3878. Online ISSN: 1526-632X.

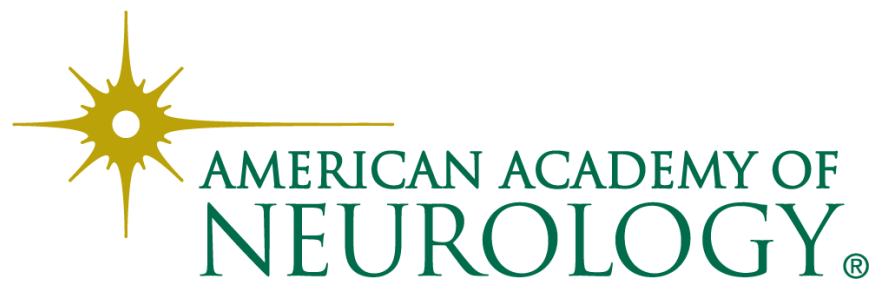

